\title{
BRANDING IN SEARCH ENGINES - OPPORTUNITIES AND THREATS
}

\begin{abstract}
Brand and its capital are now one of the company's most important intangible assets. A strong, well-positioned brand stands out against others and therefore improves competitive advantage. Web search engines are commonly used to review brand reviews and this find information in them to significantly shape the reputation of the product or service. The article attempts to identify the opportunities and threats of using image positioning, and hence the search engine reputation (SERM). To achieve the research objective, the case study method was applied. The article argues for the need to manage the reputation of a company on the Web, showing in this context the specificity of search engines.
\end{abstract}

Keywords: brand, strong brand, brand reputation, SERM, Internet search engines

\section{Introduction}

You have to do a lot of good deeds to build a good reputation, but one bad is enough to lose it - the words of B. Franklin aptly describe the challenge facing modern businesses. The dynamic development of information and communication technologies, resulting in immediate information exchange, makes reputation management more difficult than ever. In addition, in today's hyper-competitive marketplace, companies have the opportunity to gain competitive advantage by leveraging the potential of their intangible assets - including a strong brand. It is therefore essential to build a brand that is, among other things, a good reputation.

The aim of this article is to identify the role of search engine reputation management (SERM) in building the reputation of today's businesses, with particular emphasis on the opportunities and threats of this strategy. 
The research hypothesis is that modern companies should take care of their reputation online, anticipating threats by continually monitoring the internet. However, ethical standards of communication are required in this process. The following research methods were used to validate research assumptions: critical literary analysis, case study and deductive reasoning.

\section{Brand reputation - characteristics and methods of measurement}

By characterizing this term, it is essential to distinguish the reputation from other strong brand characteristics, such as image and identity, from the very beginning. In the literature of the subject, there is no universal agreement, whether there are relations between these concepts or are they separate concepts. ${ }^{1}$

Brand identity is understood as a vision of a potential consumer's perception of the brand, or a desirable way of perceiving it, created by a brand sponsor. ${ }^{2} \mathrm{~A}$ brand image means the collection of perceptions of the brand by its buyers. According to R.L. Keller, brand image refers to a set of brand associations that consumers have in mind. ${ }^{3}$ The starting point for this statement was the definition of brand image proposed by H. Herzog, who proposed to understand this concept as "brand perception mirrored by associations with the brand stored in consumer's memory". Brand associations include the importance of branding for consumers. Positiveness, strength and uniqueness of the associations are dimensions that define the knowledge of brands, which plays an important role in identifying various branding reactions, especially with a great deal of involvement in the buying process. According to K.L. Keller associations can be classified according to three main categories: qualities, benefits and attitudes. ${ }^{5}$

According to T. Dąbrowski's proposal, reputation can be understood as "[...] based on existing, consistent business activities shared by different stakeholder groups, a stable assessment of its ability and willingness to meet their expectations and providing them with a defined value". ${ }^{6}$ A. Kwiecien indicates that reputation must be understood as a complex corporate asset, shaped by a unique identity and

1 T. Dąbrowski, Reputacja przedsiębiorstwa. Tworzenie kapitału zaufania, Oficyna Wydawnicza Wolters Kluwer, Kraków 2010, p. 72.

2 J. Kall, Silna marka, PWE, Warszawa 2001, p. 25.

${ }^{3}$ K.L. Keller, Conceptualizing, Measuring and Managing Customer-Based Brand Equity, "Journal of Marketing" 1993, vol. 57, p. 3.

${ }^{4} \mathrm{H}$. Herzog, Behavioral Science Concepts for Analyzing the Consumer, [in:] P. Bliss (ed.), Marketing and the Behavioral Sciences, Allyn and Bacon Inc., Boston 1963, pp. 76-86.

${ }^{5}$ Ibidem, p. 5.

6 T. Dąbrowski, Reputacja przedsiębiorstwa..., p. 75. 
a coherent image. In his view, reputation is therefore a more general concept, comprising the two mentioned components (Tab. 1). ${ }^{7}$

A different approach is proposed by K. Majchrzak, who points to the following relation: identity influences the image, which in turn forms a reputation. ${ }^{8}$ This means that reputation is the sum of partial, accumulated images. Reputation can also be identified with "a long term image".

Table 1. Brand reputation and its components

\begin{tabular}{|l|l|}
\hline \multicolumn{2}{|c|}{ Brand reputation } \\
\hline Brand image & Brand identity \\
\hline
\end{tabular}

Source: own study based on: A. Kwiecień, Company Reputation Management, Wydawnictwo Akademii Ekonomicznej w Katowicach, Katowice 2010, p. 23.

Some of the authors identify the reputation of a company with an opinion of the company. Such an approach represents, inter alia, A. Adamus-Matuszyńska, who points to the difference between image and reputation. The image is identified with the characteristics of the company, and reputation is the opinion that consumers give the company. ${ }^{9}$

In conclusion, the strong link between reputation, brand image and brand identity should be emphasized. Certainly, they are not identical. It is important to state that reputation is the result of identity that shapes the brand image and consumer experience acquired through brand interaction. The result of this experience is to produce an opinion on the product/service or - broader - about the brand.

\section{Image positioning as a method of creating brand reputation in search engines}

Image positioning allows an organization to retain control over the search results that appear on brand queries. This long-standing process is about building a high position in the search results for inquiries related to a given brand or company.

7 A. Kwiecień, Zarządzanie reputacja przedsiębiorstwa, Wydawnictwo AE w Katowicach, Katowice 2010, p. 23.

${ }^{8}$ K. Majchrzak, Zarządzanie reputacja korporacyjna we współczesnej gospodarce, [in:] R. Maćkowska, H. Przybylski (eds.), Public relations. Aktualne zagadnienia sztuki komunikowania $w$ teorii i praktyce, Wydawnictwo AE w Katowicach, Katowice 2009, pp. 291-292.

9 A. Adamus-Matuszyńska, Reputacja. Nieuchwytna wartość firmy, online source: https://docplayer.pl/218892-Reputacja-nieuchwytna-wartosc-firmy.html [entered: 4.10.2018]. 
Table 2 shows the most common actions taken by companies in search engine image positioning, their specific characteristics, and the desired effects. SERM (search engine reputation management) is a systemic action that builds brand reputation on the web in the context of interrelated queries directed to Google. SERM results should be controlled by search results that send potential customers/users to websites, services, discussion forums, for the web containing the desired feedback. The key is that these pages are on the first page of search results. ${ }^{10}$

Table 2. Actions taken by the company in search engine positioning

\begin{tabular}{|l|l|l|}
\hline \multicolumn{1}{|c|}{ Action taken } & \multicolumn{1}{|c|}{ Characteristics } & $\begin{array}{l}\text { The intentional effects of image } \\
\text { positioning }\end{array}$ \\
\hline Monitoring comments & $\begin{array}{l}\text { Continuous monitoring of onli- } \\
\text { ne content in the context of the } \\
\text { brand, brand name, etc. }\end{array}$ & $\begin{array}{l}\text { Anticipating image crises, inte- } \\
\text { racting with branded internet } \\
\text { users, the ability to respond } \\
\text { immediately. }\end{array}$ \\
\hline Deleting negative comments & $\begin{array}{l}\text { Sending requests for removal } \\
\text { of ratings or reviews to the site } \\
\text { admin on which the negative } \\
\text { listing of the brand was posted. }\end{array}$ & $\begin{array}{l}\text { Ability to remove untruthful, } \\
\text { misleading entries, other brands, } \\
\text { etc. }\end{array}$ \\
\hline Positioning of unique articles & $\begin{array}{l}\text { Positioning a specific website } \\
\text { with the desired content for the } \\
\text { brand. }\end{array}$ & $\begin{array}{l}\text { Enhancing the position of the } \\
\text { desired brand name information } \\
\text { in the search engine. }\end{array}$ \\
\hline Positioning valuable opinions & $\begin{array}{l}\text { Encouraging satisfied customers } \\
\text { to share opinions about the } \\
\text { brand online, link and post on } \\
\text { their own positive review site. }\end{array}$ & $\begin{array}{l}\text { High positioning of positive } \\
\text { reviews and branding comments } \\
\text { in search results on it. }\end{array}$ \\
\hline Adwords campaigns & $\begin{array}{l}\text { Google Advertising System for } \\
\text { displaying sponsored links on } \\
\text { Google search results. }\end{array}$ & $\begin{array}{l}\text { Display - in the sponsored } \\
\text { results area - the link desired by } \\
\text { a company. }\end{array}$ \\
\hline
\end{tabular}

Source: own elaboration.

It is worth emphasizing that companies often take action to manage their search engine image at a time when the reputation of the brand has been tarnished. However, it is extremely difficult to remove negative comments or opinions, especially if they have been added via popular social networking sites. An example of such a service is TripAdvisor, an American opinion aggregator on tourism and catering companies. Brand representatives can relate to the review, preparing the so-called. "Management response", the removal of the negative opinion itself is a difficult,

10 T. Orzechowski, Wizerunek marki w wyszukiwarce wizerunkiem marki online, Marketer+, 15.10.2013, online source: https://marketerplus.pl/teksty/artykuly/wizerunek-marki-w-wyszukiwarce-wizerunkiem-marki-online/ [entered: 10.10.2017]. 
multi-step process and is unwillingly accepted by the site administrator. Deleting negative comments - even if it is possible - also raises ethical concerns, which can also have a negative impact on brand reputation.

To further illustrate the importance of search engine information for brand reputation - and consequently purchase decisions - it is worthwhile to refer to Google's research results in 2017. ${ }^{11}$ More than half of respondents (50.4\%) are looking for product information, only one page in search. For one third of respondents $(32.3 \%)$ the opinions of other users are completely irrelevant. The respondents also asked about the number of negative reviews/articles that caused the product to be abandoned. More than $20 \%$ of respondents stated that one article or opinion was needed to make a decision. This study shows how important it is to maintain control over the emerging views of the first page of the search engine. The branding information found on the first page of search engine results can significantly influence the reputation of the brand and, consequently, the decision to purchase the product.

\section{Opportunities and threats of using image positioning - case study}

The case study method was used to investigate the opportunities and threats to brand reputation. This is a research method that focuses on one or more examples of a social phenomenon. It's key characteristics are as follows ${ }^{12}$ :

- the purpose of the study, which is a comprehensive case and its context;

- treatment of the units of analysis, consisting in a multi-faceted approach to the phenomenon in the context of its temporal, spatial, cultural, political, institutional and social connections.

This article focuses on examples illustrating the use (or lack thereof) of the tools used in the search engine image search strategy. Selected examples concern the issue of monitoring brand information, lack of action to promote positive feedback on a product or service.

\section{British Airways}

Monitoring your online brand information is the starting point for proper branding of your brand in search engines. This is a necessary process, as illustrated by the case study of British Airways. One unsatisfied customer, Hasan Syed, who lost his

11 Research carried out by a research agency Pew Research Center in 2014, on a sample of 1000 Americans. T. Balinas, 5 Ways Online Reviews Are Affecting Your Business, online source: Outbound Engine, https://www.outboundengine.com/blog/5-ways-online-reviews-affecting-businessstats/ [entered: 12.10.2017].

${ }_{12}$ M. Strumińska-Kutra, I. Koładkiewicz, Studium przypadku, [in:] D. Jemielniak (ed.). Badania jakościowe. Metody i narzędzia, Wydawnictwo Naukowe PWN, Warszawa 2012, pp. 1-40. 
baggage at the airport, posted a negative review on the social networking site Twitter, commenting on the event he experienced and criticizing the customer service offered by British Airways. In addition, Hasan used the so-called post which was sponsored, thanks to which his entry in a very quick time gained very wide reach and was commented by thousands of people around the world. British Airways reacted to this tweet only after 10 hours - so it was too late to limit the range of the negative entry and limit the number of bad comments. ${ }^{13}$ It is important to note that web monitoring is now an easy way for Internet tools - including the ability to set up Google Alerts. Another option is to use media monitoring applications offered by, among others, Brand 24 and Sotrender.

\section{Krypotinite Locks}

Another interesting example is the American padlock manufacturer, which sells them around the world under the Kryptonite Locks brand. When searching for product information, after typing the brand name in the search engine window, next to the official manufacturer's website, a video is shared on the YouTube social networking site that teaches how to open these padlocks with a pen and a link to an article in the popular American Wired magazine on the same subject. ${ }^{14}$ It is worth mentioning that the film dates back to 2008 - brand owners did not try to position positive content (sponsored articles, positive reviews) so that search results on the first page did not display the content.

\section{Solgaz}

The Polish gas plate manufacturer, Solgaz, used its marketing communication to whisper, including generating positive feedback about its products. In addition, Internet users have also accused the brand of using certificates and test results, which are far from true. After the discovery of manipulation, the reputation of the online brand has deteriorated significantly - there have been negative reviews, including numerous publications on the Wykop discussion forum and in Internet comparisons, among others, Ceneo. Furthermore, by checking Google search results for the "Solgaz Feedback", the top 10 links listed still appear as a link to the article describing the whole case. ${ }^{15}$

13 B.P. Eha, Angry Customer Used Promoted Tweets to Chastise British Airways, Enterpreneur, 3.09.2013. Online source: https://www.entrepreneur.com/article/228175 [entered: 10.10.2017].

${ }_{14}$ Blue Fountain Media, Search Engine Reputation Management: Kryptonite Locks Case Study, 19.06.2017, online source: https://www.bluefountainmedia.com/blog/search-engine-reputation-management-kryptonite-locks-case-study/ [entered: 10.10.2017].

${ }^{15}$ K. Kopańko, Potężny kryzys polskiego producenta AGD. Internauci nie zostawili na nim suchej nitki, Spider's Web, 01.2017, online source: https://www.spidersweb.pl/2017/01/solgaz-opinie-wykop.html [entered: 15.10.2017]. 
This example illustrates the risk of unethical building and managing the brand image in the network. In the case of identifying such abuses, including, for example, the branding of flattery at your own address in the form of false opinions, the risk of PR crisis is enormous. A prospective customer looking for a product review will discover that the feedback is unreliable and that the company it self is not trustworthy.

\section{Summary}

In the light of the above considerations, managing brand reputation in search engines seems to be an indispensable activity for building a strong market position. Contemporary consumers - prosumers are eager to find information about the brand themselves, get acquainted with the opinions of other users, and learn about brands from different sources. Often, the first contact with a brand is to see Google search results.

However, it is important to emphasize that the SERM process is extremely difficult and demanding - firstly, it requires monitoring information that appears on the brand on the Internet. Secondly, it is relatively difficult to remove negative reviews - usually the site administrators allow this only if the entry is false or is due, for example, to a harmful competition. The question of removing or manipulating consumer opinions is also ethically questionable - and in the case of discovery of such manipulation by consumers, it is very negatively perceived by them.

Reputation management in search engines should be a continuous process and strongly linked to other areas of business activities - e-marketing activities, i.e. SEO and SEM, as well as - customer service policy.

\section{Bibliography}

Adamus-Matuszyńska A., Reputacja. Nieuchwytna wartość firmy, online source: https:// docplayer.pl/218892-Reputacja-nieuchwytna-wartosc-firmy.html [entered: 04.10.2018].

Babbie E., Badania społeczne w praktyce, Wydawnictwo Naukowe PWN, Warszawa 2007.

Blue Fountain Media, Search Engine Reputation Management: Kryptonite Locks Case Study, 19.06.2017, online source: https://www.bluefountainmedia.com/blog/search-engine-reputation-management-kryptonite-locks-case-study/ [entered: 10.10.2017].

Dąbrowski T., Reputacja przedsiębiorstwa. Tworzenie kapitału zaufania, Oficyna Wydawnicza Wolters Kluwer, Kraków 2010.

Eha B.P., Angry Customer Used Promoted Tweets to Chastise British Airways, Enterpreneur, 3.09.2013, online source: https://www.entrepreneur.com/article/228175 [entered: 10.10.2017].

Herzog H., Behavioral Science Concepts for Analyzing the Consumer, [in:] P. Bliss (ed.), Marketing and the Behavioral Sciences, Allyn and Bacon Inc., Boston 1963, pp. 76-86. 
Kall J., Silna marka, PWE, Warszawa, 2001.

Keller K.L., Conceptualizing, Measuring and Managing Customer-Based Brand Equity, "Journal of Marketing" 1993, vol. 57.

Kopańko K., Potężny kryzys polskiego producenta AGD. Internauci nie zostawili na nim suchej nitki, Spider's Web, 01.2017, online source: https://www.spidersweb.pl/2017/01/solgaz-opinie-wykop.html [entered: 15.10.2017].

Kwiecień A., Zarządzanie reputacja przedsiębiorstwa, Wydawnictwo AE w Katowicach, Katowice 2010.

Majchrzak K., Zarządzanie reputacją korporacyjnq we współczesnej gospodarce, [in:] Maćkowska R., Przybylski H. (eds.), Public relations. Aktualne zagadnienia sztuki komunikowania $w$ teorii i praktyce, Wydawnictwo UE w Katowicach, Katowice 2009.

Balinas T., 5 Ways Online Reviews are Affecting Your Business, online source: Outbound Engine, https://www.outboundengine.com/blog/5-ways-online-reviews-affecting-businessstats/ [entered: 12.10.2017].

Strumińska-Kutra M., Koładkiewicz I., Studium przypadku, [in:] D. Jemielniak (ed.), Badania jakościowe. Metody i narzędzia, Wydawnictwo Naukowe PWN, Warszawa 2012.

Wojcik K., Public relations. Wiarygodny dialog z otoczeniem, Placet, Warszawa 2009. 